\title{
Battle lines are drawn
}

\section{Washington}

UNDER pressure from both animal welfare groups and scientists, two groups with widely divergent views of how the government should regulate the use of research animals, the US Department of Agriculture (USDA) last week opted for a compromise; it issued comprehensive new rules on the care of guinea-pigs, hamsters and rabbits, but inserted language to ensure that few laboratories will be forced to buy new cages or make other expensive changes to conform.

The new rules are the first of two controversial sets of regulations to make it all the way through the regulatory process and to be published in the Federal Register. Both have been the subject of a fiveyear struggle between the agency, Congress and activists. As such, the battle over them has been mostly one of principle; the guinea-pig and rabbit regulations are seen as a precedent-setter for the still-unresolved and much more contentious regulations for non-human primates and dogs (see Nature 345, 755; 28 June 1990).

At issue is the concept of "performancebased" versus "engineering" regulations. Scientists argue that they should be given some leeway to design animal caging that does not exactly conform to some minimum size standard as long as they can show that the animals are healthy and happy. Animal welfare lobbyists, on the other hand, say such performance-based regulations are unenforceable, and that anything other than strict size standards are no standards at all. The Animal Legal Defense Fund, which has sued USDA to release the primate and dogs rules, is considering a lawsuit over the guinea-pig and rabbit regulations as well.

Although the new guinea-pig and rabbit regulations lay out strict cage-size mini- mums, they are "grandfathered" - they apply only to new caging bought after the rules take effect next month. More importantly, the rules allow an exemption for "innovative enclosures that do not precisely meet the space requirements". What that means is that good cages are not necessarily standard boxes, says John Miller who, as director of the animal welfare office of the National Institutes of Health (NIH), helped to write the new regulations. Because, for example, hamsters prefer walls to open spaces, if one were to design a hamster cage that was a series of interconnected tubes, which maximize the wall area but may not quite meet the minimum floor space requirement, the enclosure would still be perfectly acceptable, Miller says.

"That's precisely why the innovative enclosures' clause was inserted - to give the regulations that performance flavour". Miller explains. But he stresses that the clause does not offer carte blanche for scientists to ignore the size standards. "Smaller than minimum does not constitute innovative", he says. At any rate, because the new regulations put into law the NIH guidelines that have been in place since 1972, almost all NIH-funded animal laboratories are already in conformance, Miller says.

The still-unfinished rules for primates and dogs are now likely to also include an similar "innovative enclosure" clause, according to Miller. Since the White House rejected the USDA's previously proposed engineering-based standards earlier this year (see Nature 344, 804; 26 April 1990), the agency has retreated to lick its wounds and rewrite the regulations in performance-based language. It intends to resubmit them for review and public comment this fall.

G. Christopher Anderson

\section{Stone voyages to JPL}

\section{Washington}

VOYAGER 2, the phenomenally successful interplanetary probe whose flyby of Neptune last year provided a much-needed boost to the National Aeronautics and Space Administration (NASA) space programme, has left yet another success in its wake. Edward Stone, Voyager's scientific director, has been selected as the next head of NASA's top planetary and robotics facility, the Jet Propulsion Laboratory (JPL). Stone will replace Lew Allen, who is retiring in December.

Stone will be taking over a laboratory that has seen much of its original robotics mission eroded by an increasing NASA emphasis towards manned space explora-

\section{Research still in favour}

\section{Paris}

THE French government has once again made education and research top priorities in its annual budget. Although ministers have been told only the global figures they can expect - it is up to them to propose how the money should be spent - education is set to receive 9 per cent more than last year and research and technology an increase of 7.5 per cent. Inflation in France is currently 2.5 per cent.

The national education budget, which includes university research, but not other state research money, will increase by FF20,000 million $(\$ 3,610$ million $)$ to FF250,000 million. The increase will be swallowed up by a major new construction drive within higher education and ambitions to create thousands of new posts in all sectors of education.

Unlike most of its neighbours, France will not decrease its defence budget next year. Jean-Pierre Chevènement, the defence minister, has apparently succeeded in fighting off proposals to cut his budget and has even won a 3 per cent increase, just ahead of inflation. But greener issues are still close to President François Mitterrand's heart: the environment ministry will see its budget up by 15 per cent in 1991 .

Ministers and civil servants now have the summer to prepare detailed budgets in time for a cabinet meeting in September.

Peter Coles

\section{UK RESHUFFLE}

\section{New minister for old}

\section{London}

ROBERT Jackson, UK minister for science and higher education, has been moved from the Department of Education and Science (DES), as part of a reshuffle of middle-ranking ministers designed to improve the Conservative government's image and performance in the run up to the next general election. Jackson had been widely criticized for his piloting through parliament of a bill introducing loans for students, and the failure to convince the major banks that they should administer the scheme. More recently, he was attacked by colleagues after joking at London's Heathrow airport that his ministerial box contained a bomb.

Michael Fallon, newly appointed to the DES, is expected to take over Jackson's responsibilities. The British scientific community will hope that Fallon's appointment introduces a more sympathetic attitude from the DES towards the need for increased funding and improved career prospects in UK science. Jackson has maintained that the UK 'brain drain' is a myth, and was labelled "the rottweiler of academia" at recent press conference by the pressure group British Scientists Abroad.

PeterAldhous years has already been set and any new direction at the laboratory will have to wait, Stone says.

G. Christopher Anderson 